\title{
Gaining Students' Literacy through Local Wisdom of Blitar: Implementing of Gerakan Literasi Sekolah (GLS)
}

\author{
Ida Putriani ${ }^{1}$, Ervika Dewi Wahyuni, Siyono² \\ 1 Universitas Islam Balitar, Indonesia \\ 2Universitas Muhammadiyah Surkarta, Indonesia
}

Corresponding Author: Ida Putriani, idaputri91@gmail.com

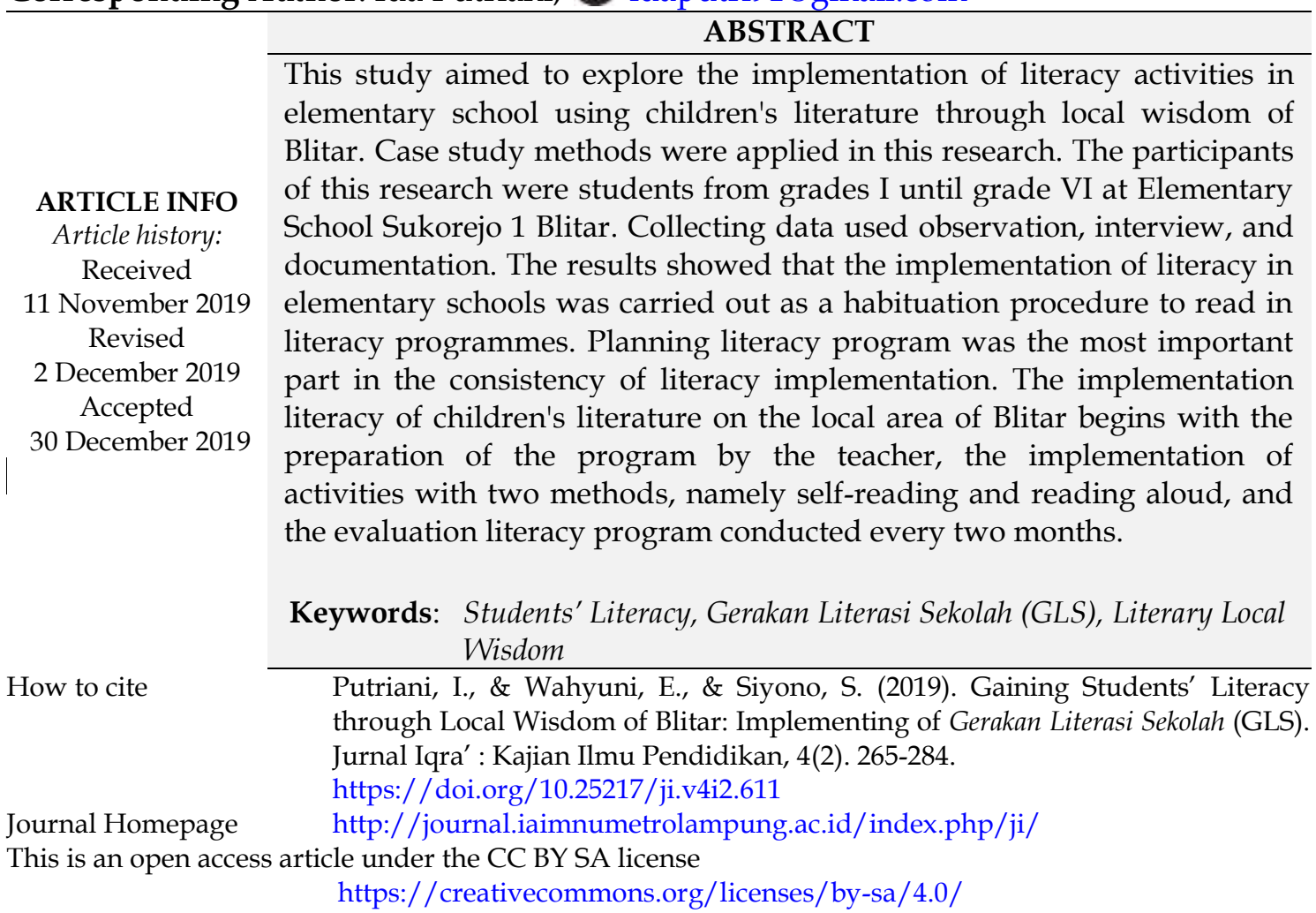

\section{INTRODUCTION}

Gerakan Lieteras Sekolah (GLS) was literacy movement with collaborative endorsement from all elements whose activities are in the form of reading habits for 15 minutes by students (Wiedarti, 2016). This activities need to be ongoing literacy training and habituation (Edwards, Neill, \& Faust, 2015). Through GLS the students are expected to have the soul and passion for lifelong reading. Students are not only able to read well but also actualize from what they have read. GLS is conducted starting from elementary school to high school by adjusting the literacy needs of the discourse in schools. Several previous studies have found GLS improve the students' knowledge in learning process. Some researchers reported the literacy movement also had done through the habituation of children at home (family digital literacy), which implanted knowledge through digital literacy in the environment of family. It 
aimed of instilling students' habits in daily life (Marsh, Hannon, Lewis, \& Ritchie, 2017; Erstad, Flewitt, Kümmerling-Meibauer, \& Pereira, 2019; Marsh et al., 2017). GLS indeed started from the habit, but the final of stage of this activity student are able to internalize a good literacy skill in each learning course, moreover as to develop lifelong learning skills (Dragoş \& Mih, 2015; Paakkari \& Paakkari, 2019). In elementary schools, the implementations of GLS were still limited at the beginning of the introduction of literacy, namely reading habit. It should be an important milestone in reaching the main points in the literacy stage. Because the habitual literacy program that does not require any outcome is misinterpreted with this activity merely as a reading and completion activity. The essence of reading to understanding the value and to build character is not fulfilled.

Other researchers reported that reading activities in GLS in elementary school was essential and have diverse challenges. For instance, starting from students' conditions is in process learning to read, the availability of a limited number of child-friendly reading resources, the less implementation reading activities program and the less facilities (English \& Watson, 2015). Rahayu (2017) also reported that the implementation of the literacy movement in schools got the problems if from every element in supporting literacy was not ready to participate. It means that it became a challenge for the implementation of GLS in elementary schools. Whereas if referring back to the main goal of GLS was to prepare students who have literate capacity and can develop literacy skills in every component of learning and in their lives. The Minister of Education and Culture Regulation No. 23 of 2015 said that GLS strengthens the movement of character development. Literacy activities not only foster children's interest in reading but also implanted character through each reading that is read by students. In other hand, Nurgiyantoro (2004) suggested that children's literature can improve in building character that tells about anything related to life's problems. Thus, it can provide information and a better understanding for students. Moreover, introducing literature which integrated local wisdom was unique concept has own positive values. It's must be known by students as part of a component in the community to guard and be normalized (Parwati, Tegeh, \& Mariawan, 2018; Vitasurya, 2016). Positive values on local wisdom can be also provides a positive character for the development of students' character and can increase their love of culture (Sumayana, 2017).

Children's literature was different from adult literature generally. Its difference was the point of view used in its preparation using the point of view of children (Sarumpaet, 2010). It means that the point of view of storytelling 
and the target was adjusted to the development and outlook of children. Children's literature has its own superiority compared to general literature if its relation used in the realm of character formation and understanding of cultural concepts. Because children's literature always presents new understanding and experience in the form of imaginative creations, with simple language exposure that describes the world of fiction that can increase science process skills, scientific attitude and students' character (Dwianto, Wilujeng, Prasetyo, \& Suryadarma, 2017; Bakti, Seni, Syarip, 2018; Hasanah, Gustini, \& Rohaniawati, 2016). Hence, by utilizing the positive values of students' literature at elementary school through simple delivery can facilitate the positive values of local wisdom.

In recent years, research on Gerakan Literasi Sekolah (GLS) has been conducted previously by several researchers. Savitz, Silva, \& Dunston (2019) reported at Mid-Sized University, located in the southeastern US. They increase knowledge through integration of literacy in understanding various contents of the subject area. Pradana, Fatimah, \& Rochana (2017) discussed attempt to establish literacy movements in students and prepare schools for the implementation of literacy movements through the formation of literacy teams in schools, making routine literacy activities programs and looking for obstacles in implementing school literacy movements. Further, Antasari (2017) emphasizes the implementation of school literacy in the habituation stage at MI Muhammadiyah. This literacy movement starts through the habituation of students in every take a rest at Taman Bacaan. They use of this simple space for reading. The development of literacy was not only enough for habituation, but also necessary to apply ethno science based guided inquiry learning as well as for character development. The next researcher was (Wandasari, 2017) discussed the implementation of the school literacy movement as an effort in shaping children's character education. This activity was carried out through the habit of reading 15 minutes at the beginning of the lesson and additional tasks in learning. Despite much progress in improving the quality of existing literacy programs in schools, there was a need to develop the teaching profession in practice, evaluation in a modified teaching system (Beecher, Abbott, Petersen, \& Greenwood, 2017).

Those previous studies gave contribution in developing literacy for students, but did not integrate literature in local wisdom. This research was more focused on the study of how the literacy activities conduct in the GLS program in elementary school by using children's literature as a source of reading and content of values, namely in the form of local wisdom values. It also different from those previous studies, because the researhers examined the 
implementation of GLS with children's literature that was contained local wisdom at Blitar, from implementation to the evaluation. Sunaryo, Nurul, and Tuti, (2017) declared that integrated local wisdom was not only understanding of adat and human knowledge, but also understanding customs, nature and relationships among community. It was contain complex sources. Hence, students were able to explain the use of children's literature in the literacy movement in elementary schools and explain the implementation of literacy using children's literature with local wisdom content.

This study was important to conduct as an effort to introduce and implant the value cultural literary in reading activities. By integrating local wisdom in literacy becomes interesting and unique thing. The students were more understand and practice the values, as well as the understanding and knowledge of customs among people. This local wisdom was a unique part that needs to be preserved from early childhood. This children's literary work was not only a means of entertainment, but also there was a content of character values that will make it easier for students to understand and internalize these values in their lives. Choosing children's literature in reading content that contains character values has a variety of characteristics, which was instill knowledge of moral values and respect for culture values. This value can be found if the students learn about local wisdom. Literature has an important position in exploring the value of local wisdom and character formation. It was closely connected with Sultoni (2017) that stated literature has the function as part of an educational vehicle in providing cultural understanding. This local wisdom value could provide students in finding their wisdom of life and interpret of life. Therefore, the aim of this study was to explain the implementation of literacy activities at elementary school using children's literature through local wisdom in Blitar.

\section{RESEARCH METHODOLOGY}

This research had employed a qualitative research with case study type. Because this study seeks to describe and analyze phenomena, events, social activities, attitudes, and perceptions of a person or group (Killam \& Heerschap, 2013; Conway, 2014). The participants were selected with cluster random sampling technique. The participant of this research were students from grades I until grade VI at Elementary School Sukorejo 1 Blitar. The researchers used observation, interview and documentation to collect the data. Observation was used to see the whole activity and the impact it causes. Observation activity carried out by observing all activities of teachers and students during the literacy activities. All activities in observation used instrument sheets. These 
activities include book selection, reading activities, and daily evaluation activities after reading.

The technique collecting data in interview was conducted of the teacher and students to find out how useful and instrumental the literacy activities have been carried out and the extent of their implementation. The researchers got data interview from Headmaster, Teacher, and Students, namely Retno Pangastuti, M.Pd as Headmaster of Elementary School Sukorejo 1 Blitar, Then teacher involve Sulistiani, S.Pd ( teacher of class 1), Septie Wahyuningwulan, S.Pd ( teacher of class 2), Purwaningtyas, S.Pd ( teacher of class 3), Denok Ratna Dumilah, S.Pd ( teacher of class 4), Suhartiwi, ( teacher of class 5), S.Pd Sumitro, S.Pd ( teacher of class 6). Moreover, the students involve Hendi, Reno Aulia Aswangga, and Naswa Camelia.

The researchers used deep interview type which was conducted at each person in charge of literacy activities in the class that is the teacher and a sample of students from each class chosen at random. The selection of in-depth interviews was intended to be naturally based on the thoughts and answers directly from the teacher and students without limiting the choice of answers. So the results obtained were more complex and natural. In interview activity the researcher was assisted by the research assistant to obtain the results of the interview. Interviewing was conducted at elementary school 1 Sukorejo, either outside of class or inside of class. The results of the interview in the form of transcript data of the results of the subsequent interviews were described qualitatively to determine the overall outline of the results of the interviews with literacy activities.

The collecting data in documentation used to view the data includes, student data, various media literacy data, and the design of the follow-up activities of the literacy activities undertaken by students. Collected data was analyzed by reducing the data, displaying the data and then concluding the data obtained as an answer to the formulation of the problem presented.

\section{RESULTS AND DISCUSSION}

The research produced the data in the form of qualitative data, namely the description of the implementation of literacy with the contents of Blitar's local wisdom. The researchers had done this study during five month. Data collection in observation had done during three months. In this case the researchers observed students from grades I until grade VI in their literacy activities in the school every 15 minutes. Other data obtained in the form of interviews with students and teacher s of the implementation of literacy activities of Gerakan Literasi Sekolah (GLS). Furthermore, the other data were 
field notes and documentation in the form of a variety of books that students use as a source of reading in literacy activities, and documentation in the form of photographs of observation activities and student literacy activities.

\section{Planning Literacy Activities by Utilizing Children's Literature Contained Character Values Based on Blitar's Local Wisdom}

Planning literacy activities based on observation, interviews, and documentation result. This study shows that planning literacy was not structured in writing by the teacher or from the school. Literacy implementation was socialized with discussions and instructions that conducted by schools through the Gerakan Literasi Sekolah (GLS). In this case, each teacher had prepared the planning program in literacy activity. The program involved choosing the variety book that contained local wisdom. Then the students continuously read in outside or inside classroom for 15 minutes.

"Literacy activities were carried out starting from grade 1 to grade 6 . Planning literacy implementation for each class depends on each teacher" (Pangastuti, Headmaster of Elementary School 1 Sukorejo, 2019, April 10). Based on the information from the teacher, each class did not prepare a special program or a special planning for literacy. It was done because in GLS in the first activity, there should not be too binding arrangements about what students read as long as it is still in accordance with the age of the students. So that it becomes a reference that the teacher did not plan for what books were read by children during literacy activities. Planning in the form of student literacy results was also not the whole class has. Based on observations and documentation studies, observations reports are not prepared, for example by using reading journals or reading logs. But it's used plain paper which is submitted to the teacher. However, there were classes that orderly in organizing reading journals, namely in class four. According to teacher of class 4 , it needs to be done because the teacher can know whether students really read or not, and the teacher can also check what students read (Wahyuningwulan, S. Teacher of Class 2 of Elementary School 1 Sukorejo, 2019, April 22). For the socialization regarding the implementation of literacy, the school only socializes activities for students, not with the guardians of students. One of the reason there was no socialization to student guardians about GLS, because the program was not an optional program. But it was a compulsory program that must be accepted by every student. Notification to student guardians was limited to the fact that there were activities in the morning before learning reading activities in the class. 
Furthermore, planning literacy based on observation, interviews, and documentation studies in (literacy planning using children's literature containing Blitar's local wisdom) were not contained a special programs or special plans. Regarding the use of children's literature as literacy media, the results of interviews with grade 1 teacher s explained that grade 1 students used children's literature as literacy sources (Sulistiani. Teacher of Class 1 of Elementary School 1 Sukorejo, 2019, May 21). It can be known from the book which was used during literacy activities. The students in grade two almost read children's literature from fairy tales, fantasy and informational books. The teacher dd not limit the type of children's literature that students can read.

Regarding the use of children's literature containing Blitar's local wisdom can be done even though it is not contained in a particular program in writing. However, literacy activities by utilizing children's literature with local wisdom are carried out through preparations carried out by each person in charge of implementing literacy in the classroom, the teacher. Each teacher is given the right to make a policy of inserting one day a week for students to get to know local wisdom through literacy activities. Literacy activities by utilizing children's literature are inseparable from the supporting elements of literacy activities namely a clear program, a literate physical environment and support from both students and teacher s.

A clear program aims at school policy in giving authority and advice to introduce local wisdom simply to students in literacy activities. The provision of literacy environment is done by demonstrating the availability of supporting facilities and infrastructure, such as reading corners with children's literary contents containing local wisdom, provision of reading resources by students and teacher s, as well as various types of children's literary genres presented. Meanwhile, the support of teacher s and students is also an important point in the implementation of literacy. This support can be done with the teacher giving examples of good reading, participating in reading during literacy activities, providing and sorting out books that fit the characteristics and needs of students about knowledge of local wisdom. Through such activities not only increase students' interest in reading or knowing about the cultural riches around them, they are able to enhance and instill their own character in students. This is consistent with what was stated by Malawi, Dewi, April (2017) that through reading and knowing culture can internalize positive characters in students. 


\section{The Implementation of Literacy through Children's Literature with Character} Values Based on Blitar's Local Wisdom

\section{The First Week}

Literacy using children's literature was practiced almost every day and overall students. "Children's literature includes the fiction story books, fantasy books, poetry books and informational books. In the process implementation, the teacher allows students to read independently" (Suhartiwi. Teacher of Class 5 of Elementary School 1 Sukorejo, 2019, April 5). The first week, the researchers observed that there was no book about Blitar's local wisdom. The evaluation was conducted by the teacher during literacy activities was also not certain. There was an evaluation by following up writing in a reading journal or reading results. However, in the high class that was the first grade and the sixth grade the teacher left the students during the literacy activities and returned to class when learning would begin. For the sixth grade, the observation was only read modestly and without summarizing their reading result because the observation was made after the implementation of the National Examination.

\section{The Second Week}

For the second week the researchers had done the observation. The students from the grade the first class until the sixth class used children's literature as a reading source.

Figure 1. The Students' Literary Activity

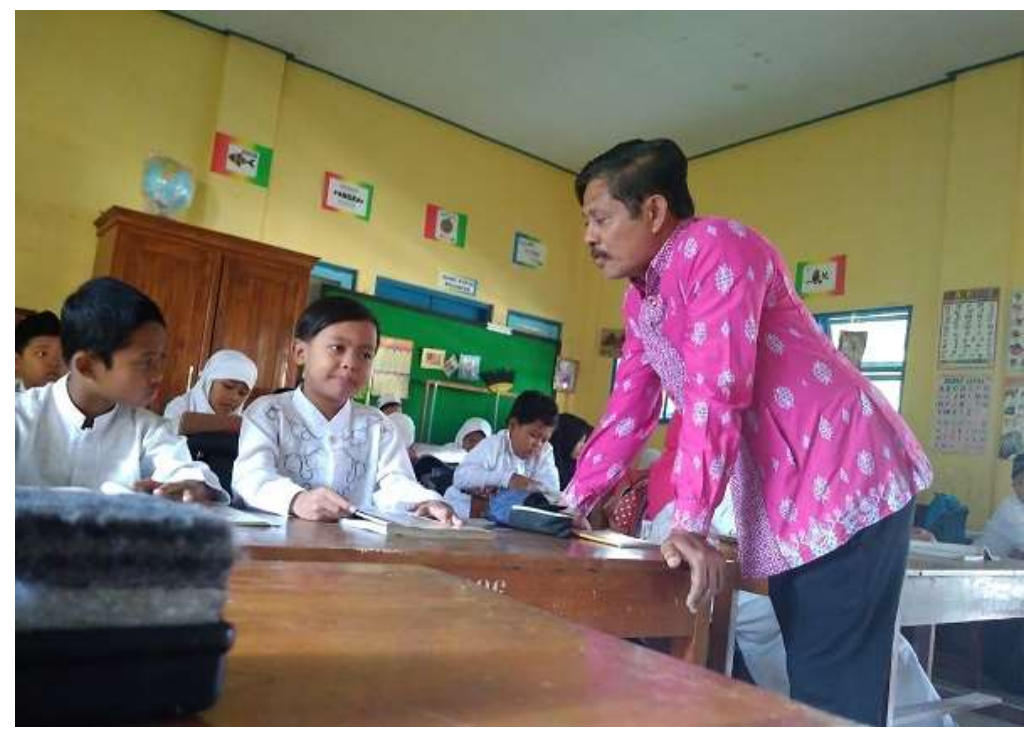

Figure 1 explained that the teacher prepare in literary activity to students. The children's literature was used many kinds. These were still the same as the previous week and new titles. This observation, the teacher took time to 
prepare literary Blitar's local wisdom. The guardians of the fifth class used the technique of reading aloud. The teacher told about the local story of Lodoyo, namely Gong Kyai Pradah. It was observed that students were quite enthusiastic in listening in each story. After finishing the story, as an evaluation the teacher conducted debriefing and discussion to students about what students get from the stories that have been explained.

\section{The Third Week}

The third week was the beginning when learning begins after the vacation of school. "Structurally, literacy program has not changed and keep on continuously. The teachers inserted some materials about Blitar's local wisdom that could help students' get to get new knowledge the value of local wisdom.

Figure 2. Reading Activity of Students in Understanding Material about Blitar's Local Wisdom

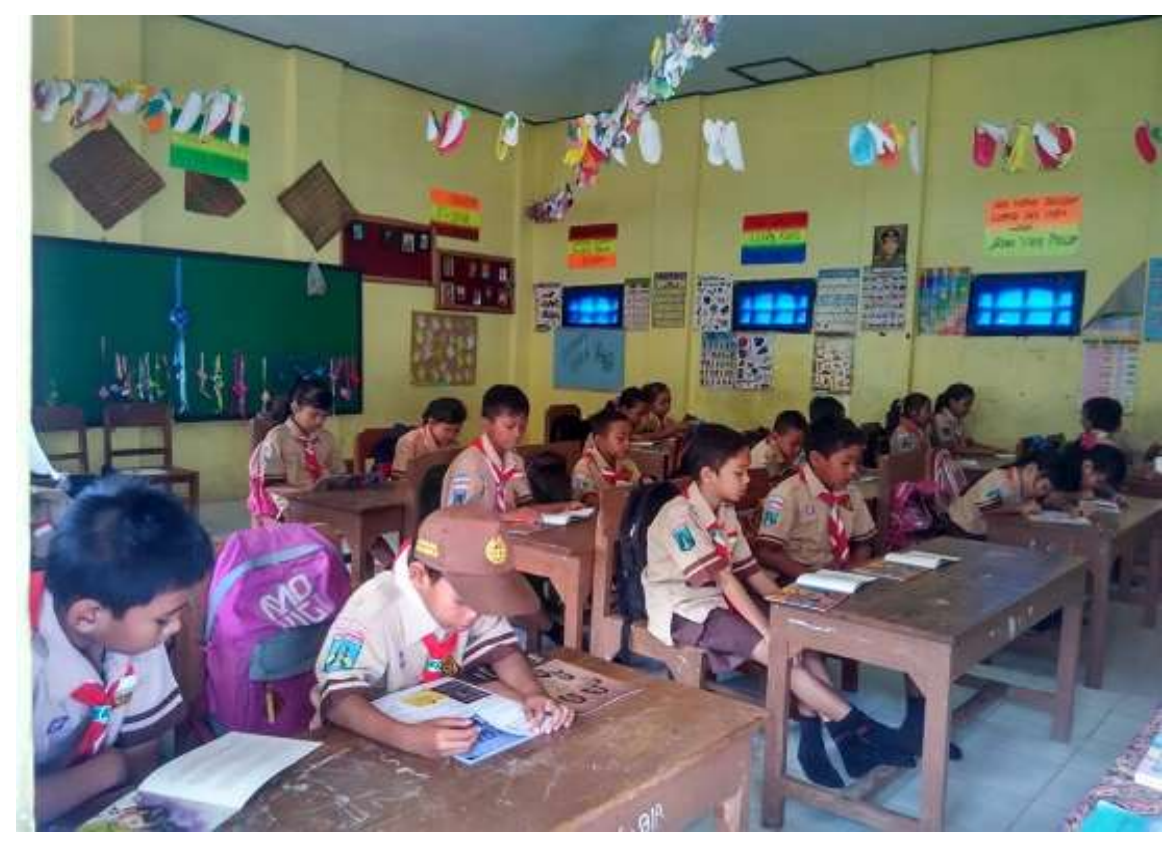

Figure 2 was the data of students' activity in reading comprehension about reading material Blitar's local wisodom. All students carried out literacy activities 15 minutes before learning began. The third week, it was observed that the homer teacher tried to insert the local wisdom of the Blitar from the result students' reading. The literary programs for this week, the teacher only conduct conditional learning. It means that the program literary not structured on a particular day for each class. The insertion activity involves debriefing each students and teacher related Blitar's local wisdom. Then, in the end of discussion the teachers gave feedback and explained deeper discussion about 
Blitar's Local Wisdom. Then the students were asked to give the moral value of what the students' read and understanding on their literary.

\section{The Fourth Week}

In this week, the overall implementation remains the same as for previous the week. The use of children's literature was the main source of students in reading both in the first until the sixth grade "(Sumitro. Teacher of Class 6 of Elementary School 1 Sukorejo, 2019, April 23). For children's literature of Blitar's wisdom-based character values, the researchers observed in the previous week. For example the teacher gave reinforcement to the students who have read. For the low class level, especially the first class and the second class, children's literature using Blitar's local wisdom has not been observed. The lack of resources literary books relate to Blitar local wisdom of, especially for low grade students, was a factor rarely used in literacy activities. However, for high class literacy, the implementation by utilizing children's literature contained character values from Blitar local wisdom, although the teacher still used the technique of reading aloud.

\section{The Fifth Week}

Figure 3. Reading Activity of Students in Understanding Material about Blitar's Local Wisdom

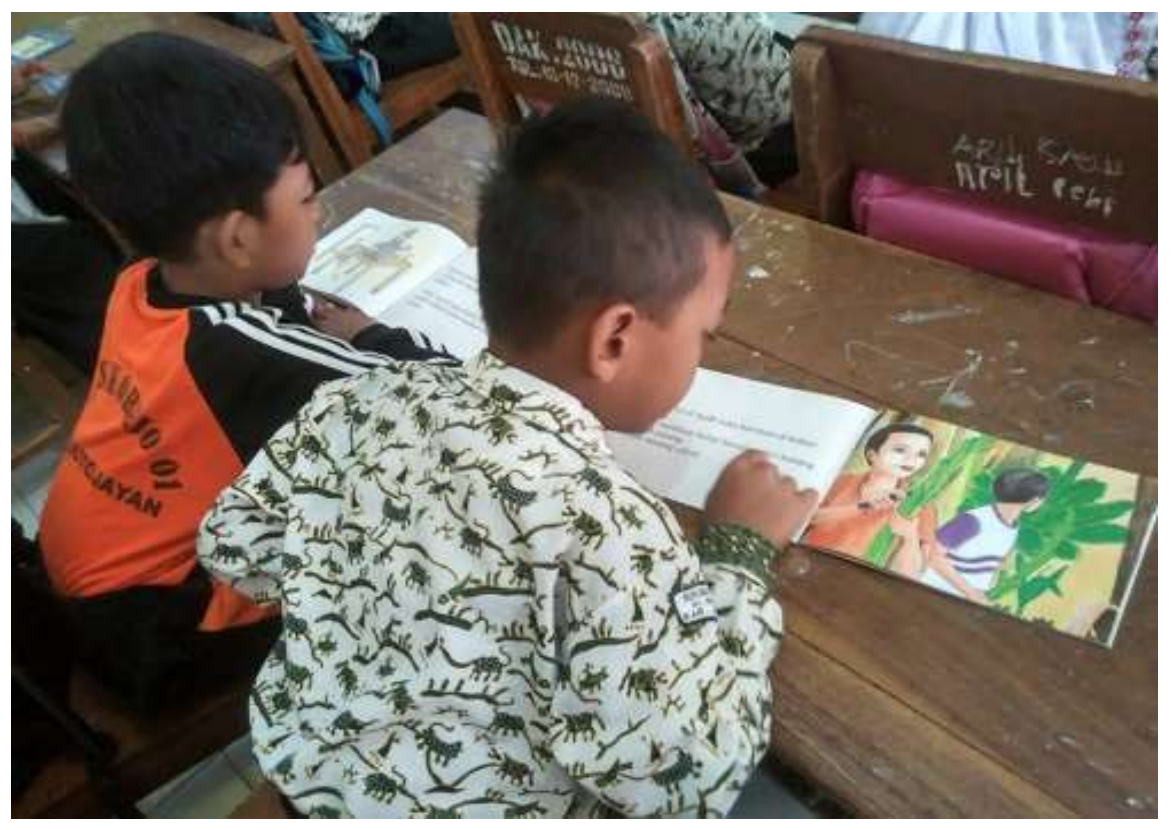

Figure 3 discussed that the children's literature was used starting from the first grade up to the sixth grade. In their learning literacy, the students prefer to read stories literacy activities instead of informational books. For informational 
books, most of the students only read the pictures from their book. Meanwhile, in children's literature the students read book contained character values based on Blitar's local wisdom. It means that there is no special day for literacy integrates Blitar's local wisdom. However, the teacher in each class teaches the introduction of Blitar's wisdom through these character values implicitly through the readings students read. besides that the teacher also chooses storytelling techniques in literacy to introduce Blitar's local wisdom.

\section{The Sixth Week}

Literacy activities in this week as a whole have used children's literature. Reading activities carried out in class and library. Students can read books independently or in pairs. In literacy activity, the students did not maximal to use reading sources of children's literature containing character values based on Blitar's local wisdom, due to the lack of reading sources. However, the teacher already has the technique, namely the storytelling technique to talk Blitar's local wisdom, the topic which was talked by the teacher not far from children's literature, starting from folklore and informational books. This technique was still being done so that all students get the same information.

\section{The Seventh Week}

Literacy activity was the same as the weeks before. It started routinely every 15 minutes before starting learning from the first grade until the seventh grade. The activity begins with students choosing their own books to read and continuing reading. The students who have not finished reading a book in one reading, it will be done in the next stages. It was done either in the level low class or high class (Suhartiwi. Teacher of Class 5 of Elementary School 1 Sukorejo, 2019, April 05). During this week the teacher continues to use the technique of reading aloud to convey to children related to children's literature contained local wisdom in Blitar. There was no specifically prepared, but the teacher conditionally conveys the character content with Blitar's local wisdom at a time during the week of literacy activities. Students also take advantages of reading materials related to Blitar to read in class and discuss with their classmates. Most of the reading material was informational books.

\section{The Eight Week}

In literacy activity the students read independently and the next they conduced debriefing to the teacher and their classmates about reading material. Just like the technique from the previous week, the teacher used storytelling techniques for literary with local wisdom based children's literature. Many

\section{5}


positive responses for students when the teachers do literacy activity in storytelling. Overall eight weeks the teacher has used children's literature as a source of reading in literacy activities, for literacy with local wisdom Blitar is carried out with loud reading techniques conveyed by the teacher.

Doing literary activities are one important part in the realization of developing children's character that is fond of reading. In accordance with the purpose of literacy which is to increase student interest in reading can also improve student character through readings that are read. Through literacy activities not only foster children's interest in reading but also instill character through each reading that is read by students. Through the aim of fostering interest and character, the selection of reading sources or types of readings is one of the basics for the implementation of the literacy program itself. Based on observations, one of the types of children's book like in literacy activities was children's literature. Not only easy to understand, but also the children's literature has various forms that make children have alternative reading choices. As stated by Nurgiyantoro (2004) that children's literature is literature that talks about anything related to life's problems so that it can provide information and a better understanding of life itself to children. Children's literary works are not only a means of entertainment, but there is also a load of character values in them that will make it easier for students to understand and internalize these values in their lives. The teacher gives freedom to students to choose the type of children's literature that students want to read.

This research has the main findings related to the implementation of literacy in the Gerakan Literasi Sekolah (GLS), especially in elementary schools of 1 Sukorejo. The first, the arranged literacy program facilitated the implementation of literacy in certain themes such as local wisdom literature. A structured and documented literacy program was an important part of literacy success. It was also explained in the literacy movement guide that planning program was the most important part in the consistency of literacy implementation. The second, the stages habituation of literacy implementation was easy process in application of students' literary in Blitar's Local Wisdom. Habituations of literacy routinely gave the direct impact on students' understanding. The consistency program in literary for students gave an effect in supporting of desire in reading process in literacy. It closely connected with Beecher (2017) that agreed the consistency of literacy activity becomes an important for children.

The third finding found that the implementation of literacy with local wisdom was not only emphasized in the program determined by the School, but also readiness of the teachers' preparation in implementation literary

\section{6}


program for students. This is in accordance with Sabirin (2012) that effective planning literary program was when the headmaster entangles the teacher in effort to develop a school program. Preparation in the program was carried out by the teacher by exploring the potential sources of local wisdom around, and students acting as enthusiasts of reading. Students also participated in conveying what they want to know and the teacher could prepare the concepts and implementation of planning. While in the implementation, the teacher was active role as the facilitator and the student as executor. The teacher as the facilitator has the role of providing relevant reading sources with local wisdom, and providing facilitation in the form of providing assistance in the delivery of students' literacy. On the other, the teacher gave the feedback of the students' literacy. While the students as executors have a role in implementation reading activities happily. The fourth finding related to the evaluation of literacy implementation. Evaluation of literacy should not be limited in evaluation of reading results, but an evaluation of the overall literacy program. Reading evaluation was conducted at the end of the literacy which is carried out every day by the teacher and students. While, the evaluation program was conducted by all element educators in school every two months. This evaluation involves all supporting elements of literacy from schools, teachers, students, and parents. Overall evaluation supports the improvement and implementation of the next literacy program. The fifth finding was the model of literacy implementation children's literature containing Blitar's local wisdom using the literacy model which supported by the oral method of teacher or student reading aloud. Literacy activity was not only be done by reading only but listening. Because the essence of literacy was not only in reading, but in reading comprehension. It finding in line with what was stated by Kharizmi (2019) that literacy was very related to the students ability in reading, writing, speaking and cultivate a process information to obtained problem solving in daily life. Thus it was not only emphasizing the process of independent reading but also how the students interpret what is obtained through reading.

The difference finding between previous research and current research emphasized in the implementation of gerakan literarsi sekolah (GLS) in schools that utilizing children's literature. In addition, this study also focuses on children's literacy with Blitar's local wisdom content that had not been studied by other research. The differences that can be found from other studies were the process of implementing literacy with local wisdom. The process included preparation, implementation and reporting. While in Malawi, Dewi, \& April (2017) emphasized the role of teachers in literacy, but the success of a literacy program requires support not only from the teacher's role but also in some 
elements, for instance, students, schools, and parents. The success of literacy implementation must have the support of teachers, school funds and all implementing agencies (Wulandari, 2017). Related to implementation, the findings found that the implementation method using read-aloud method to help the teacher and student obtain information from children's literature with local wisdom. It also different from what was stated by Faradina (2017) that obstacles in GLS occurred when students reading aloud. On the findings current research, the method of reading aloud was one alternative in the variety of literacy activities. The activity of reading aloud was not only done by students but also demonstrated by the teacher. Through this method of reading students were taught to focus on listening and of course in understanding the contents read. In addition, this method also facilitates limited availability of limited local wisdom reading resources.

The importance of children's literature as a source of reading is of concern to the teacher. Then it is followed up with the provision of reading material in the form of children's literature either in the classroom reading corner or in the library. Various types of children's literature for instance fiction books, fantasy story books, poetry, and informational books trying to be filled and equipped to become readings that can help students. Children's literature is not only interesting but also describes the moral value. Through read various types of children's literature, the students not only learn about literal understanding of the reading, but are also able to use meaning or value in their reading books. It relevant with the research by Rahayu (2016) said that in growing and implementing a good literacy, need the strategy in implementation. This strategy are (1) conditioning the literacy-friendly physical environment, (2) working on the social environment and affective as a literacy model of communication and interaction, (3) striving for the schools as a literal academic environment. Those statements are fulfilled in the literacy activities at SDN 1 Sukorejo, namely schools that provide literacy facilities and infrastructure, create literate environments by carrying out simultaneous literacy every day and carrying out follow-up from the results of literacy activities. Literacy is inseparable from careful planning. Although the literacy activities have been stated in the GLS rules, each school should have a plan or program related to this literacy. The clarity of this program will certainly have an impact on what students will get. The teacher as a good tutor of the class prepares the important things related to the class. As stated by Modelu \& Pido (2019) that one of the things teachers should do is to be free to take initiative and be creative in carrying out programs because it must be free from 
bureaucratic attachments that usually hinder the implementation of educational programs. Of course, a planning is the most important thing to do.

Literacy activities at elementary school 1 Sukorejo have been carried out according to instructions from the GLS program, although with some notes. It is indicated by the activities that have been routinely carried out every day and support from the element in literacy success, for instance starting from the availability of planning by the person in charge of literacy and supporting of a literal physical environment. Beside, the application of literacy of this school used oral literacy method and all literacy activity all literacy activities carried out have used children's literature as the main reading material. It can be explained that the implementation of literacy activities in GLS by using children's literature inserted with local wisdom Blitar is divided into several stages. This stage is carried out in one literacy activity which consists of the stages of planning, implementation, and reporting. The implementation chart is as follows:

Figure 4.

Workflow of Gerakan Literasi Sekolah (GLS) at Elementary School 1 Sukorejo

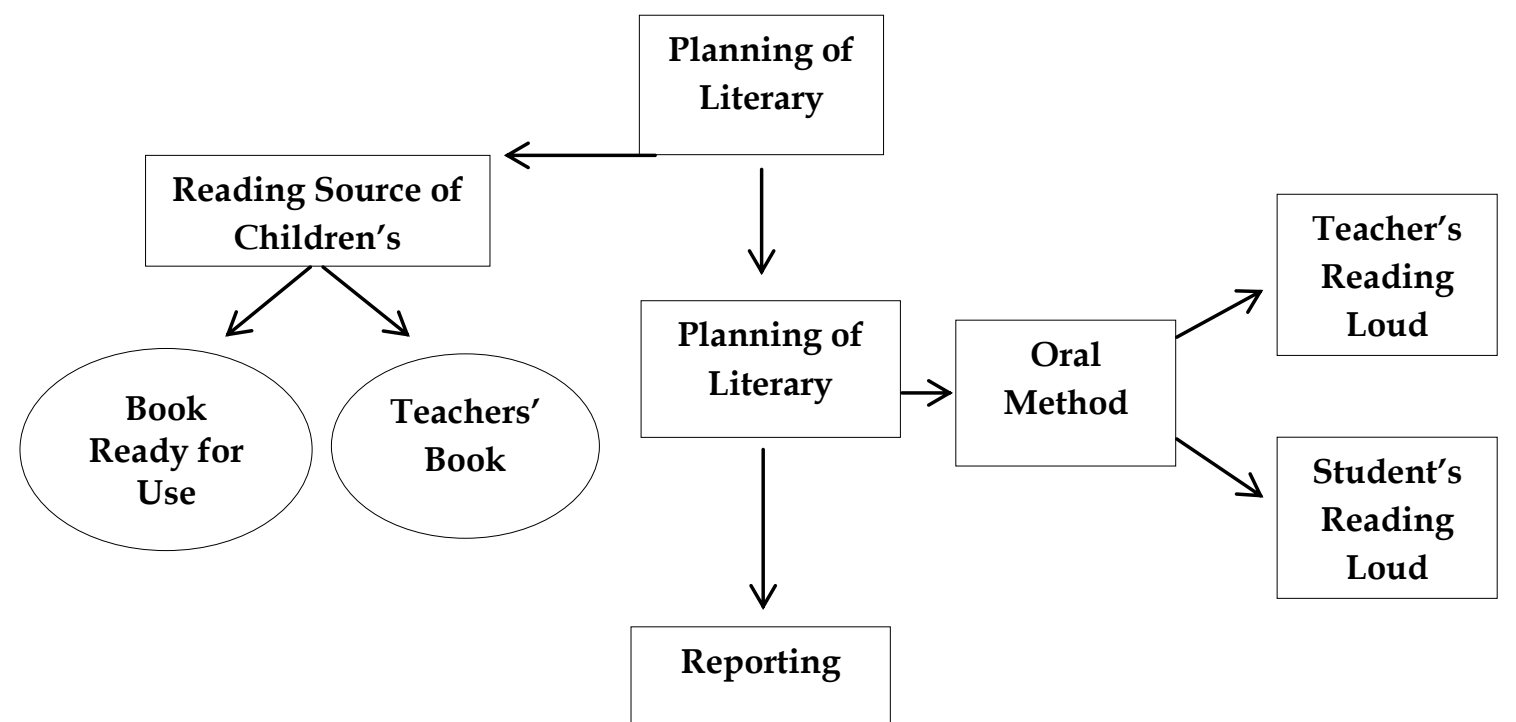

Source: The Researchers Process in GLS, April - June, 2019.

Figure 4 discussed the planning stage includes the selection of reading sources, and planning for implementation. The students have the freedom to choose reading source. Children's literature that used consists of various types or genres from fairy tales, short stories, fantasy fiction, poetry, and folklore. At the implementation stage, the use of children's literature based on Blitar's local wisdom cannot be done by students' reading independently because of limited reading resources. Hence, the teachers used oral method that is reading aloud 
technique. This technique is used by the teacher to convey reading material related to Blitar's local wisdom. Reading techniques carried out in literacy are not tied to one particular method, but can use different methods. As stated by Widyaningrum (2016) that one of the literacy learning techniques is the provision of various models and examples of effective literacy practices. Through the different methods, it is expected to be able to connect the lack of reading source suggestions relating to children's literature containing Blitar's local wisdom. In the reporting stage, is the stage undertaken by students in literacy activities in oral and written forms. Verbal reporting is done with debriefing independently which is then continued classically on the reading results. Meanwhile, written reporting is done by asking the students to make reading logs or reading notes on their paper. It is accordance with the concept of literacy itself, which is not just a reading activity but has a close relationship with writing. It equal to the Eanes (1997) who said that reading and writing activities as an integrated skill called literacy. Literacy activities are not only focuses on reading books but also in implementing and interpreting what is read in the form of a piece of writing.

\section{CONCLUSION}

The implementation of literacy activities in GLS, especially in elementary school requires cooperation in all supporting elements of literacy. These elements include the teacher, students, infrastructure, the availability of reading resources and structured programs. Literacy implementation by utilizing children's literature based on local wisdom of Blitar at elementary school 1 Sukorejo 01 has been implemented. Furthermore, structured programs were limited to simple class planning activities, implementation with limited sources of reading local wisdom through reading loud and reporting in the form of follow-up in the oral and reading log.

\section{ACKNOWLEDGMENTS}

The authors were sincere appreciation to Minister of Research, Technology, and Higher Education, Republic of Indonesia. This research was founded by funding Minister of Research, Technology, and Higher Education, Republic of Indonesia with Number 526/M/KPT.KP/2018, on September 17, 2018. The author also extend gratitude to Drs. Soebiantoro, M,Si as Rector University of Balitar who had given advice how to conduct this research. Lastly, acknowledgments are extended to Retno Pangastuti,M.Pd as Headmaster of Elementary School 1 Sukorejo. 


\section{AUTHOR CONTRIBUTION STATEMENTS}

Ida Putriani (IP) was the main author in this paper. Ervika Dewi Wahyuni (EDW) was the second author who provided support in being a comparative researcher. IP as the main researcher was the lecturer of Primary School Teacher Education Department at University Islam at Balitar. IP was researcher and developing methods. EDW and SS helped researcher to evaluate the implementation of literary program.

\section{REFERENCES}

Antasari, I. W. (2017). Implementasi Gerakan Literasi Sekolah Tahap Pembiasaan di MI Muhammadiyah Gandatapa Sumbang Banyumas. Libria, 9(1).Google Scholar.

Bakti, T , Seni A, dan Syarip H. (2018). Buku Cerita Anak berbasis Kearifan Lokal Kelom Geulis Tasikmalaya untuk Siswa Sekolah Dasar. PEDADIDAKTIKA: Jurnal Ilmiah Pendidikan Guru Sekolah DasarVol. 5, No. 1 (2018) 232-241.Google Scholar.

Beecher, C. C., Abbott, M. I., Petersen, S., \& Greenwood, C. R. (2017). Using the Quality of Literacy Implementation Checklist to Improve Preschool Literacy Instruction. Early Childhood Education Journal, 45(5), 595-602. https://doi.org/10.1007/s10643-016-0816-8.

Conway, C. M. (2014). The Oxford Handbook of Qualitative Research in American Music Education. Oxford University Press. Google Scholar.

Dragoş, V., \& Mih, V. (2015). Scientific Literacy in School. Procedia - Social and Behavioral Sciences, 209, 167-172. https:/ / doi.org/10.1016/j.sbspro.2015.11.273.

Dwianto, A., Wilujeng, I., Prasetyo, Z. K., \& Suryadarma, I. G. P. (2017). The Development of Science Domain Based Learning Media Which is Integrated with Local Potention to Improve Science Process Skill and Scientific Attitude. Jurnal Pendidikan IPA Indonesia, 6(1). https://doi.org/10.15294/jpii.v6i1.7205.

Edwards, A. H., Neill, P., \& Faust, P. B. (2015). Literacy Coaching: Middle School Academic Achievement and Teacher Perceptions Regarding Content Area Literacy Strategy Instruction. Alabama Journal of Educational Leadership, 2, 15-25.Google Scholar.

Eanes, R. (1997).Content Area Literacy: Teaching for Today and Tomorrow. Albany: Delmar Publisher.Google Scholar.

English, L. D., \& Watson, J. M. (2015). Statistical Literacy in the Elementary School: Opportunities for Problem Posing. Dalam F. M. Singer, N. F. 
Ellerton, \& J. Cai (Ed.), Mathematical Problem Posing (hlm. 241-256). https://doi.org/10.1007/978-1-4614-6258-3_11.

Erstad, O., Flewitt, R., Kümmerling-Meibauer, B., \& Pereira, Í. S. P. (2019). The Routledge Handbook of Digital Literacies in Early Childhood. Routledge.Google Scholar.

Faradina , N. (2017) . Pengaruh Program Gerakan Literasi Sekolah Terhadap Minat Baca Siswa di SD Islam Terpadu Muhammadiyah An-Najah Jatinom Klaten. Jurnal Hanata Widya, (Online), 6(8): 60-69. Google Scholar.

Hasanah, A., Gustini, N., \& Rohaniawati, D. (2016). Cultivating character education based on sundanese culture local wisdom. Jurnal Pendidikan Islam, 2(2), 231-253. Google Scholar.

Kharizmi, M. 2019. Kesulitan siswa sekolah dasar dalam meningkatkan kemampuan literasi. Jurnal Pendidikan Almuslim, 2(2): 94-102. Google Scholar.

Killam, L. A., \& Heerschap, C. (2013). Challenges to student learning in the clinical setting: A qualitative descriptive study. Nurse Education Today, 33(6), 684-691. https:/ / doi.org/10.1016/j.nedt.2012.10.008.

Malawi I, Dewi T, dan Apri K. (2017). Peran Guru alam Membudayakan Literasi Di Sekolah Dasar Melalui Sastra Lokal. Prosiding Seminar Hasil Penelitian dan Pengabdian Kepada Masyarakat UNIPMA 2017. FKIP, Universitas PGRI Madiun.Google Scholar.

Marsh, J., Hannon, P., Lewis, M., \& Ritchie, L. (2017). Young children's initiation into family literacy practices in the digital age. Journal of Early Childhood Research, 15(1), 47-60. https:// doi.org/10.1177\%2F1476718X15582095.

Modelu, R., \& Pido, A. (2019). Manajemen Peningkatan Mutu Berbasis Sekolah (MPMBS): antara Harapan dan Realita di SMA Negeri 3 Atinggola. AlMinhaj: Jurnal Pendidikan Islam, 2(1), 128-142. http:/ / dx.doi.org/10.25078/jpm.v3i1.89.

Nurgiyantoro, B. (2004). Sastra Anak: Persoalan Genre. Jurnal Humaniora, Volume 16, No. 2, Juni2004:107-122.Google Scholar.

Oktavianti, Ika, dkk. (2017). Menggagas Kajian Budaya Lokal Di Sekolah Dasar Melalui Gerakan Literasi Sekolah. Prosiding seminar nasional aktualisasi kurikulum 2013 di sekolah dasar melalui gerakan literasi sekolah untuk menyiapkan generasi unggul dan berbudi pekerti. 15 maret 2017.Google Scholar. 
Paakkari, O., \& Paakkari, L. (2019). Health literacy and the school curriculum: The example of Finland. USA: International Handbook of Health Literacy.Google Scholar .

Parwati, N. N., Tegeh, I. M., \& Mariawan, I. M. (2018). Integrating the Values of Local Wisdom into the Learning Model: Building Positive Student Character. Dalam K. A. Persichitte, A. Suparman, \& M. Spector (Ed.), Educational Technology to Improve Quality and Access on a Global Scale (hlm. 297-307). https:/ / doi.org/10.1007/978-3-319-66227-5_23.

Pradana, B. H., Fatimah, N., \& Rochana, T. (2017). Pelaksanaan Gerakan Literasi Sekolah Sebagai Upaya Membentuk Habitus Literasi Siswa Di Sma Negeri 4 Magelang. Solidarity: Journal of Education, Society and Culture, 6(2), 167-179.Google Scholar.

Rahayu, T. (2016). Penumbuhan Budi Pekertimelalui Gerakan Literasi Sekolah. Progresive and Fun Education Seminar. ISBN:978-602-361-045-7. Google Scholar.

Sabirin. 2012. Perencanaan Kepala Sekolah Tentang Pembelajaran. Jurnal Tabularasa, (Online), 9(1): 111- 128, Google Scholar

Sarumpaet, RK. (2010). Pedoman Penelitian Sastra Anak. Jakarta: Yayasan Obor Indonesia.Google Scholar.

Savitz, R. S., Silva, A., \& Dunston, P. J. (2019). Situated Learning, the SecondaryEducation Preservice/In-service Teacher, and the Taming of the Literacy Education Shrew. The Clearing House: A Journal of Educational Strategies, Issues and Ideas, 92(6), 224-234. https://doi.org/10.1080/00098655.2019.1675573.

Sumitro. (April 23, 2019). The Result Interview, Teacher of Class 6, at Elementary School 1 Sukorejo

Sultoni, A dan Hubbi S. (2015). Pembelajaran Sastra Berbasis Kearifan Lokal Sebagai Upaya Optimalisasi Pendidikan Karakter Kebangsaan Menuju Masyarakat Ekonomi ASEAN (MEA). Seminar Nasional Pendidikan Bahasa Indonesia 2015. ISSN: 2477-636X.Google Scholar.

Suhartiwi. (April 05, 2019). The Result Interview, Teacher of Class 5, at Elementary School 1 Sukorejo.

Sulistiani. (May 21, 2019). The Result Interview, Teacher of Class 1, at Elementary School 1 Sukorejo.

Sumayana, Y. (2017). Pembelajaran Sastra Di Sekolah Dasar Berbasis Kearifan Lokal (Cerita Rakyat). Mimbar Sekolah Dasar, 4(1), 21-28. http:/ / doi.org/10.23819/mimbar-sd.v4i1.5050.

Sunaryo, H, Nurul Z , dan Tuti K. (2017). Model Adaptasi Nilai Kearifan Lokal dalam Pembelajaran Sastra Berkarakter. SOSIOHUMANIKA: Jurnal 
Pendidikan Sains Sosial dan Kemanusiaan, Vol.10(1) May, pp.107116. Google Scholar.

Vitasurya, V. R. (2016). Local Wisdom for Sustainable Development of Rural Tourism, Case on Kalibiru and Lopati Village, Province of Daerah Istimewa Yogyakarta. Procedia - Social and Behavioral Sciences, 216, 97-108. https://doi.org/10.1016/j.sbspro.2015.12.014.

Wahyuningwulan, S. (April 22, 2019). The Result Interview, Teacher of Class 2, at Elementary School 1 Sukorejo.

Wandasari, Y. (2017). Implementasi Gerakan Literasi Sekolah (GLS) Sebagai Pembentuk Pendidikan Berkarakter. JMKSP (Jurnal Manajemen, Kepemimpinan, dan Supervisi Pendidikan), 2(2). http:/ / dx.doi.org/10.31851/jmksp.v2i2.1480.

Widyaningrum, L. (2016). Membudayakan Literasi Berbasis Manajemen Sekolah (Aplikasi, Tantangan dan Hambatan). Jurnal DIMAS, (Online), 16 (1): 125-144, (http://www.id.portalgaruda.org), diakses 16 Agustus 2019. http:/ / dx.doi.org/10.21580/dms.2016.161.895.

Wiedarti, P, dkk. (2016). Desain Induk Gerakan Literasi Sekolah. Jakarta: Direktorat Jenderal Pendidikan Dasar dan Menengah Kementerian Pendidikan dan Kebudayaan.Google Scholar.

Wulandari, R. (2017).. Implementasi Kebijakan Gerakan Literasi Sekolah di Sekolah Dasar Islam Terpadu Lukman Al Hakim Internasional. Jurnal Kebijakan Pendidikan, (Online), 6(3): 319-330.Google Scholar.

Copyright Holder :

(c) Putriani, I., Wahyuni, E., \& Siyono. (2019).

First Publication Right :

(C) Jurnal Iqra' : Kajian Ilmu Pendidikan

This article is under:

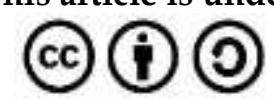

